\title{
Peningkatan Hasil Belajar Materi Pecahan dengan Menerapkan Model Problem Based Learning dengan Media Manipulatif
}

\author{
Norma Dewi Anjani ${ }^{*}$, Joko Suliantoํ․ Mei Fita Asri Untari ${ }^{3}$ \\ ${ }^{123}$ Universitas PGRI Semarang, Semarang, Indonesia
}

\author{
A R T I C L E I N F O \\ Article history: \\ Received 11 February \\ 2021 \\ Received in revised form \\ 22 March 2021 \\ Accepted 10 April 2021 \\ Available online 15 May \\ 2021 \\ Kata Kunci: \\ Hasil Belajar, PBL, Media \\ Manipulatif. \\ Keywords: \\ Learning Outcomes, $P B L$, \\ Manipulative Media.
}

\begin{abstract}
A B S T R A K
Penggunaan model pembelajaran dan media pembelajaran yang kurang bervariasi menyebabkan pembelajaran menjadi tidak menarik minat belajar siswa dan hasil belajar siswa menjadi rendah, sehingga dibutuhkan model pembelajaran dan media yang dapat menarik minat belajar siswa. Penelitian ini bertujuan untuk menganalisis penerapan model $P B L$ dengan media manipulatif terhadap hasil belajar pada Materi Pecahan siswa kelas V sekolah dasar. Penelitian ini termasuk penelitian tindakan kelas. Subjek penelitian ini adalah hasil belajar materi pecahan, dan objek penelitian ini adalah seluruh siswa kelas V di SDN 2 Jono. Metode pengumpulan data menggunakan metode tes. Instrumen yang digunakan berupa tes tertulis essai. Data yang didapatkan akan dianalisis dengan teknik analisis data statistik kuantitatif. Hasil penelitian menunjukkan bahwa peningkatan hasil belajar siswa menggunakan model PBL dengan media manipulatif terbukti dari hasil evaluasi prasiklus $13,79 \%$ meningkat pada siklus I menjadi $62,07 \%$, kemudian
\end{abstract} pada siklus II meningkat menjadi $86,21 \%$. Simpulan penelitian ini adalah penerapan model pembelajaran $P B L$ dengan media manipulatif dapat meningkatkan hasil belajar pada materi pecahan siswa kelas V sekolah dasar. Implikasi penelitian ini adalah siswa dilibatkan pada kegiatan belajar, siswa dilatih untuk tetap bekerja sama, siswa dapat memperoleh pemecahan maslah, meningkatkan percaya diri, meningkatkan minat pada diskusi dan motivasi pada proses pembelajaran, memberikan kesempatan untuk berkolaborasi serta multisensori dan menimbulkan variasi dalam belajar.

\begin{abstract}
A B S T R A K
The use of learning models and learning media that are less varied causes learning to not attract student learning interest and student learning outcomes to be low, so that learning models and media are needed that can attract student learning interest. This study aims to analyze the application of the PBL model with manipulative media on learning outcomes in the Fraction Material of grade $V$ elementary school students. This research is a classroom action research. The subjects of this study were the learning outcomes of fraction material, and the object of this study were all fifth grade students at SDN 2 Jono. Methods of data collection using the test method. The instrument used was a written essay test. The data obtained will be analyzed using quantitative statistical data analysis techniques. The results showed that the increase in student learning outcomes using the PBL model with manipulative media was evident from the results of the pre-cycle evaluation of $13.79 \%$, increasing in the first cycle to $62.07 \%$, then in the second cycle it increased to $86.21 \%$. The conclusion of this research is that the application of the PBL learning model with manipulative media can improve learning outcomes on fraction material of grade $V$ elementary school students. The implication of this research is that students are involved in learning activities, students are trained to continue to work together, students can get problem solving, increase self-confidence, increase interest in discussion and motivation in the learning process, provide opportunities for collaboration and are multisensory and cause variations in learning.
\end{abstract}




\section{Pendahuluan}

Keberhasilan dalam belajar dapat dilihat dari pencapaian hasil belajar yang diperoleh. Hasil belajar merupakan hasil akhir dari sebuah pembelajaran, karena hasil belajar menggambarkan keberhasilan atau kegagalan dalam proses pembelajaran. Hasil belajar adalah kemampuan yang dimiliki siswa setelah mengikuti proses belajar mengajar (Ladimiyanto, 2014; Mariani, 2017; Saraswati et al., 2013). Kemampuan tersebut mencakup pada ranah kognitif yang meliputi pengetahuan, pemahaman, penerapan, analisis, sintesis dan penilaian. Ranah afektif yang berupa menerima, menanggapi, menilai, mengelola, dan menghayati. Ranah psikomotor meliputi peniruan, manipulasi, pengalamiahan dan artikulasi. Hasil belajar dalam penelitian ini menekankan pada ranah kognitif. Penilaian yang digunakan berupa tes tertulis pilihan jamak.

Matematika sebagai ilmu yang tidak dapat dipisahkan dari dunia pendidikan dan mempunyai peranan yang sangat penting dalam mencetak SDM yang berkualitas. Hal ini dikarenakan matematika adalah ilmu yang berhubungan dengan penalaran dan pola pikir manusia. Matematika merupakan salah satu bagian dari ilmu dasar (basic science) yang memiliki peran penting di era kemajuan ilmu pengetahuan dan teknologi. Untuk itu Pembelajaran matematika diharapkan akan menjadi solusi akhir yang tepat, valid dan dapat diterima secara ilmiah oleh dunia pendidikan (Dewiyanti, 2018; Febriyanti \& Seruni, 2015; Wintari et al., 2014).

Rendahnya hasil belajar matematika sering menjadi masalah bagi siswa, sehingga guru dan orang tua harus berupaya untuk memecahkan masalah tersebut. Masih banyak guru dalam proses pembelajarannya menggunakan metode ceramah artinya siswa pasif, kegiatan belajar mengajar didominasi guru (teacher centered). Oleh karena itu, dalam proses pembelajaran matematika diperlukan suatu metode mengajar yang bervariasi. Mata pelajaran matematika perlu diberikan kepada peserta didik untuk membekali peserta didik dengan kemampuan berpikir logis, analitis, sistematis, kritis, dan kreatif, serta kemampuan bekerjasama minimal mampu memecahkan masalah yang dihadapi dalam kehidupan sehari-hari (Alhakiki \& Taufina, 2020; Rustinah, 2016; Tarigan, 2014). Misalnya berdagang, berkebun, bertani bahkan mengurus rumah tanggapun memerlukan pengetahuan tentang ilmu hitung dalam matematika. Untuk itu penting kiranya untuk mempelajari ilmu matematika sejak dini.

Berdasarkan hasil observasi di SDN 2 Jono, lembaga pendidikan mengelola secara optimal semua komponen pembelajaran berupa pendidik, siswa, kurikulum, bahan ajar, iklim pembelajaran, media pembelajaran, fasilitas belajar dan materi belajar ditata sedemikian rupa sehingga mampu menghasilkan proses dan hasil belajar yang optimal. Praktik di lapangan, menunjukkan masih banyak permasalahan dalam dunia pendidikan di Indonesia khususnya pada pembelajaran Matematika. Melihat data hasil belajar dan pelaksanaan pembelajaran pada mata pelajaran matematika kelas V SDN 2 Jono, perlu sekali adanya upaya untuk meningkatkan kualitas pembelajaran yang dapat mendorong siswa untuk aktif, kreatif, mandiri, kerjasama dan toleransi dalam pembelajaran sehingga hasil belajar siswa dan ketuntasan hasil belajar tercapai. Maka salah satu satu solusi yang ditawarkan adalah menerapkan model pembelajaran Problem Based Learning.

Problem Based Learning adalah seperangkat model pembelajaran yang berfokus pada masalah untuk mengembangkan keterampilan berpikir, menyelesaikan masalah dan keterampilan intelektual siswa. Dimana model pembelajaran ini sangat tepat digunakan dalam pembelajaran matematika yang erat kaitannya dengan peristiwa kehidupan sehari-hari karena matematika bersifat objektif. Menurut (Defiyanti \& Sumarni, 2019; Pratiwi \& Setyaningtyas, 2020; Rais \& Suswanto, 2017), Problem Based Learning memiliki ciri-ciri bahwa dalam pembelajarannya dimulai dari suatu masalah yang memiliki konteks dengan dunia nyata, pebelajar secara aktif merumuskan masalah dan mengidentifikasi kesenjangan pengetahuan mereka, mempelajari serta mencari sendiri materi yang terkait dengan masalah, lalu melaporkan solusi dari masalah, sementara pendidik lebih banyak memfasilitasi. Sebagai model pembelajaran, ada lima tahap pembelajaran pada Problem Based Learning. Lima tahap ini sering disebut tahap interaktif, yang juga sering disebut sintaks dari Problem Based Learning. Lama waktu yang dibutuhkan untuk menyelesaikan tiap tahapan pembelajaran tergantung pada jangkauan masalah yang diselesaikan.

Sintaks model Problem Based Learning yaitu Orientasi siswa pada situasi masalah, Mengorganisasi siswa untuk belajar, membimbing penyelidikan individual maupun kelompok, mengembangkan dan menyajikan hasil karya, menganalisis dan mengevaluasi proses pemecahan masalah (Ariswati, 2018; Ariyanti, 2017; Istiandaru et al., 2015). Model pembelajaran Problem Based Learning memiliki kelebihan dan kelemahan. Kelebihan dari model ini yaitu, siswa dilibatkan pada kegiatan belajar sehingga pengetahuannya diserap dengan baik, siswa dilatih untuk tetap bekerja sama dengan siswa lain, dan siswa dapat memperoleh pemecahan dari berbagai (Abdurrozak \& Jayadinata, 2016; Gunantara et al., 2014; Purbarani et al., 2018). 
Menurut (Adawiyah, 2018; Novitasari, 2018; Ramlawati et al., 2017) Problem Based Learning adalah seperangkat model mengajar yang menggunakan masalah sebagai fokus untuk mengembangkan keterampilan pemecahan masalah, materi, dan pengaturan diri. Model pembelajaran ini lebih dari sekedar lingkungan yang efektif untuk mempelajari pengetahuan tertentu. Ia dapat membantu pemelajar membangun kecakapan sepanjang hidupnya dalam memecahkan masalah. Sehingga Problem Based Learning ini tepat digunakan dalam pembelajaran matematika yang memiliki karakteristik objektif, yaitu terkait dengan peristiwa yang terjadi dalam kehidupan sehari-hari (Juliawan et al., 2017; Nurhayati \& Angraeni, 2017; Yuwono \& Syaifuddin, 2017).

Salah satu media yang bisa digunakan yaitu media manipulatif. Media manipulatif merupakan benda-benda, alat-alat, atau model konkret, yang dapat disentuh, digerak-gerakan oleh siswa untuk membantu dalam memahami selama proses pemecahan masalah yang berkaitan dengan suatu konsep atau topik matematika (Diawati, 2018; Firdaus et al., 2018; Wicaksana, 2017). Media manipulatif dalam pembelajaran matematika di SD adalah alat bantu pembelajaran yang digunakan terutama untuk menjelaskan konsep dan prosedur matematika. Media manipulatif memiliki karakteristik dapat dimanipulasi untuk penyampaian materi sesuai dengan tujuan pembelajaran yang ingin dicapai.

Media manipulatif memiliki karakteristik dapat digunakan untuk mengefisienkan waktu dalam penyampaian materi. Media pembelajaran dalam dunia pendidikan tidak pernah terlepas dari kelebihan dan kekurangan. Begitu pula dengan media manipulatif. Kelebihan dari media manipulatif antara lain meningkatkan percaya diri, meningkatkan minat pada diskusi dan motivasi pada proses pembelajaran, memberikan kesempatan untuk berkolaborasi serta multisensori dan menimbulkan variasi dalam belajar (Ernawati, 2014; Setianingsih, 2019; Sulfemi \& Mayasari, 2019). Sedangkan kekurangan dari media manipulatif antara lain tidak tersedia untuk semua (kebutuhan) orang dan dapat membuat ketergantungan pada penggunanya.

Perpaduan antara model pembelajaran Problem Based Learning dengan media manipulatif ini akan membuat pembelajaran Matematika menjadi lebih menarik, sehingga siswa antusias dalam mengikuti pembelajaran. Pernyataan tersebut didukung oleh pendapat (Erwanto, 2020; Febriana et al., 2020; Sucipto, 2017) bahwa media manipulatif merupakan alat bantu pelajaran yang digunakan oleh guru dalam menerangkan materi pelajaran dan berkomunikasi dengan siswa, sehingga mudah memberi pengertian kepada siswa tentang konsep materi yang diajarkan dengan menggunakan benda-benda yang didesain seperti benda nyata yang dekat dengan kehidupan siswa sehari-hari, seperti buah-buahan, binatang, alat transportasi berupa mainan dan manik-manik yang dengan mudah diutak-atik atau diubahubah.

Penelitian ini didukung dengan beberapa penelitian terdahulu yang relevan yaitu: (1) penelitian yang dilakukan oleh (Ariswati, 2018), yang memperoleh hasil penelitian bahwa model pembelajaran Problem Based Learning berpengaruh terhadap hasil belajar matematika siswa kelas V SD; (2) penelitian yang dilakukan oleh (Suwarni, 2019), yang memperoleh hasil penelitian bahwa model pembelajaran Problem Based Learning (PBL) dengan media audio visual terbukti dapat meningkatkan prestasi belajar siswa pada mata pelajaran PKN; (3) penelitian yang dilakukan oleh (Febriana et al., 2020), yang memperoleh hasil penelitian bahwa modul geometri ruang berbasis Problem Based Learning terbukti berpengaruh terhadap kreativitas pemecahan masalah yang dihadapi oleh siswa.

Tujuan penelitian ini adalah untuk menganalisis penerapan model Problem Based Learning (PBL) dengan media manipulatif terhadap hasil belajar pada Materi Pecahan siswa kelas V SD Negeri 2 Jono Kecamatan Tawangharjo Tahun 2020/2021.

\section{Metode}

Penelitian ini termasuk penelitian tindakan kelas. Penelitian ini didasarkan atas konsep pokok bahwa penelitian terdiri dari empat komponen pokok yang juga menunjukkan langkah dalam penelitian, yaitu: Perencanaan atau planning, Tindakan atau acting, Pengamatan atau observing dan Refleksi atau reflecting. Hubungan antara keempat komponen tersebut menunjukkan sebuah siklus atau kegiatan. Subjek penelitian ini adalah hasil belajar materi pecahan siswa kelas V SD Negeri 2 Jono Kecamatan Tawangharjo Tahun 2020/2021, dan objek penelitian ini adalah seluruh siswa kelas V di SDN 2 Jono. Penelitian ini dilaksanakan di SD Negeri 2 Jono Kecamatan Tawangharjo. Metode pengumpulan data menggunakan metode tes. Instrumen yang digunakan berupa tes tertulis essai. Instrumen yang peneliti gunakan untuk menilai tingkat keberhasilan peserta didik adalah Rencana Pelaksanaan Pembelajaran atau RPP. Intrumen pengumpulan data yang digunakan antara lain tes pra siklus, evaluasi/tes, lembar Observasi dan dokumentasi. Teknik analisis data yang digunakan dalam penelitian ini adalah teknik perbandingan, yaitu suatu teknik analisis data dengan membandingkan hasil pengamatan sebelum dilakukan tindakan dengan setelah dilakukan tindakan. Analisis perbandingan ini dilakukan sejak 
dilakukan tindakan I (siklus I) sampai tindakan berakhir. Hasil perbandingan digunakan sebagai bahan refleksi. Perbandingan nilai hasil observasi tentang pemahaman siswa dan hasil belajar dalam mengikuti pembelajaran Matematika pada setiap siklus seharusnya meningkat. Perbandingan hasil belajar dilakukan dengan membandingkan nilai rata-rata kelas, jumlah ketuntasan belajar, nilai tertinggi dan nilai terendah. Dengan asumsi antara lain nilai rata-rata kelas, nilai tertinggi, nilai terendah dan jumlah siswa yang tuntas seharusnya meningkat serta jumlah siswa yang belum tuntas seharusnya berkurang.

\section{Hasil dan Pembahasan}

Berdasarkan hasil penelitian yang telah dilakukan, peneliti menyajikan hasil penelitian dalam bentuk tabel dan diagram. Berikut disajikan hasil belajar siswa dari prasiklus sampai siklus II dapat dilihat pada Tabel 1.

Tabel 1. Hasil Belajar Siswa

\begin{tabular}{|c|c|c|c|}
\hline Kriteria & PraSiklus & Siklus I & Siklus II \\
\hline Nilai Rata-rata & 43.45 & 67.24 & 78.97 \\
\hline Nilai Tertinggi & 85 & 90 & 95 \\
\hline Nilai Terendah & 10 & 30 & 50 \\
\hline Siswa Tuntas & 4 & 18 & 25 \\
\hline Siswa Tidak Tuntas & 25 & 11 & 4 \\
\hline
\end{tabular}

Berdasarkan Tabel 1, dapat disimpulkan bahwa nilai rata-rata dari prasiklus sampai siklus II meningkat, nilai tertinggi dan terendah juga meningkat, begitu pula dengan jumlah siswa yang tuntas juga meningkat dari prasiklus sampai siklus II. Sedangkan jumlah siswa yang tidak tuntas menurun dari prasiklus sampai siklus II. Terbukti bahwa dengan menerapkan model Problem Based Learning dengan media manipulatif mampu meningkatkan hasil belajar siswa dan ketuntasan belajar siswa kelas V di SD Negeri 2 Jono sesuai dengan asumsi yang telah ditentukan. Untuk lebih jelasnya, diagram perbandingan hasil belajar siswa dapat dilihat pada Gambar 1.

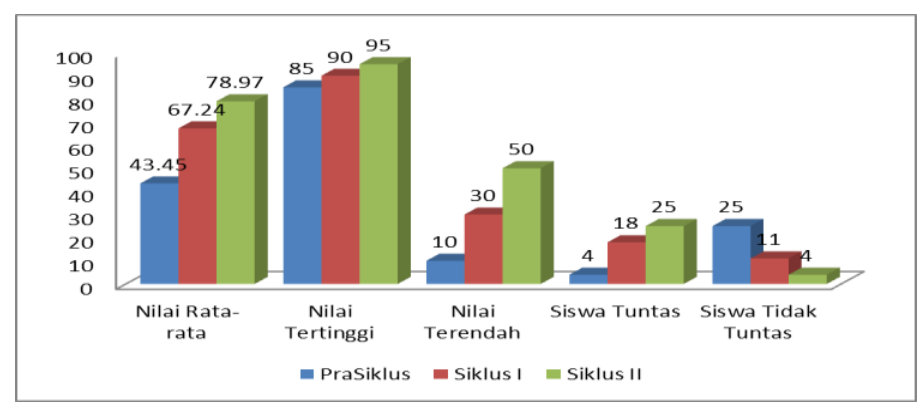

Gambar 1. Diagram Perbandingan Hasil Belajar Siswa

Berdasarkan Gambar 1, jelas terlihat bahwa semua asumsi terpenuhi terbukti dengan nilai ratarata, nilai tertinggi, nilai terendah dan jumlah siswa yang tuntas meningkat dari prasiklus sampai siklus II. Begitu pula dengan jumlah siswa yang tidak tuntas menurun dari prasiklus sampai siklus II.

Berdasarkan hasil penelitian yang telah dilakukan, peneliti menyajikan hasil penelitian dalam bentuk tabel dan diagram. Berikut disajikan perbandingan aktivitas siswa dari prasiklus sampai siklus II berdasarkan indikator penilaian dapat dilihat pada Tabel 2 .

Tabel 2. Aktivitas Siswa

\begin{tabular}{lccc}
\hline \multicolumn{1}{c}{ Aspek } & Prasiklus & Siklus I & Siklus II \\
\hline Siswa berminat dalam proses pembelajaran & $13,79 \%$ & $68,97 \%$ & $93,10 \%$ \\
Siswa aktif mencari jawaban & $13,79 \%$ & $62,07 \%$ & $86,21 \%$ \\
Siswa aktif dalam kerja kelompok & $13,79 \%$ & $55,17 \%$ & $79,31 \%$ \\
\hline \multicolumn{1}{c}{ Rata-rata } & $\mathbf{1 3 , 7 9 \%}$ & $\mathbf{6 2 , 0 7 \%}$ & $\mathbf{8 6 , 2 1} \%$ \\
\hline
\end{tabular}


Berdasarkan Tabel 2, dapat disimpulkan bahwa nilai rata-rata dari semua aspek meningkat tiap siklus. Begitu pula dengan presentase aspek juga meningkat dari prasiklus sampai siklus II. Terbukti bahwa dengan menerapkan model Problem Based Learning dengan media manipulatif mampu meningkatkan minat belajar siswa sehinga mendorong meningkatnya hasil belajar dan ketercapaian ketuntasan belajar siswa kelas V di SD Negeri 2 Jono sesuai dengan asumsi yang telah ditentukan. Untuk lebih jelasnya, diagram perbandingan aktivitas belajar siswa dapat dilihat pada Gambar 2 .

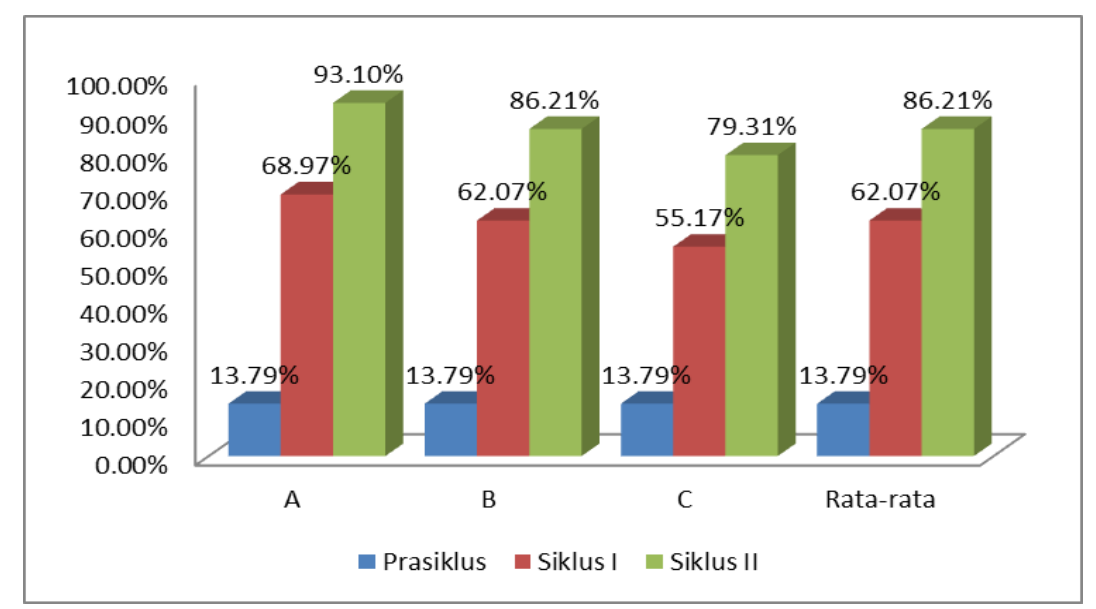

Gambar 2. Diagram Perbandingan Aktivitas Belajar Siswa

Berdasarkan diagram di atas, jelas terlihat bahwa setiap aspek meningkat dari prasiklus sampai siklus II. Begitu pula dengan rata-rata dari semua aspek ikut meningkat dari prasiklus sampai siklus II. Maka dapat disimpulkan bahwa penerapan model pembelajaran Problem Based Learning (PBL) dengan media manipulatif dapat meningkatkan hasil belajar pada materi pecahan siswa kelas V SD Negeri 2 Jono Kecamatan Tawangharjo Tahun 2020/2021.

Problem Based Learning adalah seperangkat model pembelajaran yang berfokus pada masalah untuk mengembangkan keterampilan berpikir, menyelesaikan masalah dan keterampilan intelektual siswa. Dimana model pembelajaran ini sangat tepat digunakan dalam pembelajaran matematika yang erat kaitannya dengan peristiwa kehidupan sehari-hari karena matematika bersifat objektif. Menurut (Defiyanti \& Sumarni, 2019; Pratiwi \& Setyaningtyas, 2020; Rais \& Suswanto, 2017), Problem Based Learning memiliki ciri-ciri bahwa dalam pembelajarannya dimulai dari suatu masalah yang memiliki konteks dengan dunia nyata, pebelajar secara aktif merumuskan masalah dan mengidentifikasi kesenjangan pengetahuan mereka, mempelajari serta mencari sendiri materi yang terkait dengan masalah, lalu melaporkan solusi dari masalah, sementara pendidik lebih banyak memfasilitasi.

Sintaks model Problem Based Learning yaitu Orientasi siswa pada situasi masalah, Mengorganisasi siswa untuk belajar, membimbing penyelidikan individual maupun kelompok, mengembangkan dan menyajikan hasil karya, menganalisis dan mengevaluasi proses pemecahan masalah (Ariswati, 2018; Ariyanti, 2017; Istiandaru et al., 2015). Model pembelajaran Problem Based Learning memiliki kelebihan dan kelemahan. Kelebihan dari model ini yaitu, siswa dilibatkan pada kegiatan belajar sehingga pengetahuannya diserap dengan baik, siswa dilatih untuk tetap bekerja sama dengan siswa lain, dan siswa dapat memperoleh pemecahan dari berbagai (Abdurrozak \& Jayadinata, 2016; Gunantara et al., 2014; Purbarani et al., 2018).

Problem Based Learning adalah seperangkat model mengajar yang menggunakan masalah sebagai fokus untuk mengembangkan keterampilan pemecahan masalah, materi, dan pengaturan diri(Adawiyah, 2018; Novitasari, 2018; Ramlawati et al., 2017). Model pembelajaran ini lebih dari sekedar lingkungan yang efektif untuk mempelajari pengetahuan tertentu. Ia dapat membantu pemelajar membangun kecakapan sepanjang hidupnya dalam memecahkan masalah. Sehingga Problem Based Learning ini tepat digunakan dalam pembelajaran matematika yang memiliki karakteristik objektif, yaitu terkait dengan peristiwa yang terjadi dalam kehidupan sehari-hari (Juliawan et al., 2017; Nurhayati \& Angraeni, 2017; Yuwono \& Syaifuddin, 2017).

Salah satu media yang bisa digunakan yaitu media manipulatif. Media manipulatif merupakan benda-benda, alat-alat, atau model konkret, yang dapat disentuh, digerak-gerakan oleh siswa untuk membantu dalam memahami selama proses pemecahan masalah yang berkaitan dengan suatu konsep atau topik matematika (Diawati, 2018; Firdaus et al., 2018; Wicaksana, 2017). Media manipulatif dalam pembelajaran matematika di SD adalah alat bantu pembelajaran yang digunakan terutama untuk 
menjelaskan konsep dan prosedur matematika. Media manipulatif memiliki karakteristik dapat dimanipulasi untuk penyampaian materi sesuai dengan tujuan pembelajaran yang ingin dicapai.

Perpaduan antara model pembelajaran Problem Based Learning dengan media manipulatif ini akan membuat pembelajaran Matematika menjadi lebih menarik, sehingga siswa antusias dalam mengikuti pembelajaran. Pernyataan tersebut didukung oleh pendapat (Erwanto, 2020; Febriana et al., 2020; Sucipto, 2017) bahwa media manipulatif merupakan alat bantu pelajaran yang digunakan oleh guru dalam menerangkan materi pelajaran dan berkomunikasi dengan siswa, sehingga mudah memberi pengertian kepada siswa tentang konsep materi yang diajarkan dengan menggunakan benda-benda yang didesain seperti benda nyata yang dekat dengan kehidupan siswa sehari-hari, seperti buah-buahan, binatang, alat transportasi berupa mainan dan manik-manik yang dengan mudah diutak-atik atau diubahubah.

Penelitian ini didukung dengan beberapa penelitian terdahulu yang relevan yaitu: (1) penelitian yang dilakukan oleh (Ariswati, 2018), yang memperoleh hasil penelitian bahwa model pembelajaran Problem Based Learning berpengaruh terhadap hasil belajar matematika siswa kelas V SD; (2) penelitian yang dilakukan oleh (Suwarni, 2019), yang memperoleh hasil penelitian bahwa model pembelajaran Problem Based Learning (PBL) dengan media audio visual terbukti dapat meningkatkan prestasi belajar siswa pada mata pelajaran PKN; (3) penelitian yang dilakukan oleh (Febriana et al., 2020), yang memperoleh hasil penelitian bahwa modul geometri ruang berbasis Problem Based Learning terbukti berpengaruh terhadap kreativitas pemecahan masalah yang dihadapi oleh siswa.

Implikasi penelitian ini adalah siswa dilibatkan pada kegiatan belajar, siswa dilatih untuk tetap bekerja sama, siswa dapat memperoleh pemecahan maslah, meningkatkan percaya diri, meningkatkan minat pada diskusi dan motivasi pada proses pembelajaran, memberikan kesempatan untuk berkolaborasi serta multisensori dan menimbulkan variasi dalam belajar.

\section{Simpulan}

Berdasarkan hasil penelitian dan pembahasan dapat disimpulkan bahwa penerapan model pembelajaran Problem Based Learning (PBL) dengan media manipulatif dapat meningkatkan hasil belajar pada materi pecahan siswa kelas V SD Negeri 2 Jono Kecamatan Tawangharjo Tahun 2020/2021. Implikasi penelitian ini adalah siswa dilibatkan pada kegiatan belajar, siswa dilatih untuk tetap bekerja sama, siswa dapat memperoleh pemecahan maslah, meningkatkan percaya diri, meningkatkan minat pada diskusi dan motivasi pada proses pembelajaran, memberikan kesempatan untuk berkolaborasi serta multisensori dan menimbulkan variasi dalam belajar.

\section{Daftar Rujukan}

Abdurrozak, R., \& Jayadinata, A. K. (2016). Pengaruh Model Problem Based Learning Terhadap Kemampuan Berpikir Kreatif Siswa. Jurnal Pena Ilmiah, 1(1), 871-880. https://doi.org/10.23819/pi.v1i1.3580

Adawiyah, R. (2018). Implementasi Metode Problem Based Learning Pada Mata Pelajaran Al-Quran dan Hadist Untuk Meningkatkan Hasil Belajar Kognitif dan Penanaman Sikap Peduli Sosial Pada siswa MTs Negeri 1 Sidoarjo. Pedagogia: Jurnal Pendidikan, 7(1), 61-67. https://doi.org/10.21070/pedagogia.v7i1.1604

Alhakiki, A., \& Taufina, T. (2020). Pengaruh Quantum Teaching Kerangka TANDUR Terhadap Hasil Belajar Matematika di Sekolah Dasar. Jurnal Basicedu, 4(3), 534-540. https://doi.org/10.31004/basicedu.v4i3.395

Ariswati, N. P. E. A. (2018). Pengaruh Model Pembelajaran Problem Based Learning Terhadap Hasil Belajar Matematika Siswa Kelas V SD Negeri Nanggulan. Mimbar PGSD, 6(4). https://doi.org/10.1590/s1809-98232013000400007

Ariyanti, M. (2017). Perbandingan keefektifan model project-based learning dan problem-based learning ditinjau dari ketercapaian tujuan pembelajaran. Jurnal Pendidikan Matematika Dan Sains, 5(1), 1 10. https://doi.org/https://doi.org/10.21831/jpms.v5i1.13469

Defiyanti, \& Sumarni, W. (2019). Analisis Kemampuan Berpikir Kritis Peserta Didik Pada Penerapan Problem Based Learning Berbantuan Lembar Kerja Peserta Didik Bermuatan Etnosains. Phenomenon, 09(2), 206-218. https://doi.org/10.21580/phen.2019.9.2.4200

Dewiyanti, N. K. (2018). Pengaruh Model Pembelajaran Team Games Tournament (TGT) Berbantuan 
Media Permainan Ular Tangga terhadap Hasil Belajar Matematika. Jurnal Imiah Pendidikan Dan Pembelajaran, 2(1). https://doi.org/10.23887/jipp.v2i1.13977

Diawati, L. P. (2018). Pengaruh Model Children's Learning in Scince Berbantuan Media Audio Visual Terhadap Kompetensi Pengetahuan IPA Siswa. Jurnal Mimbar Ilmu, 23(2), 113-121. https://doi.org/10.23887/mi.v23i2.16417

Ernawati, E. (2014). Pemanfaatan Media Pembelajaran Audio Visual Untuk Meningkatkan Hasil Belajar PAI Pada Siswa Kelas V SDN Kalianget Timur X. Pedagogia: Jurnal Pendidikan, 3(2), 81-87. https://doi.org/10.21070/pedagogia.v3i2.59

Erwanto. (2020). Profil Kemampuan Berpikir Kritis Siswa Pada Konsep Keanekaragaman Hayati Melalui Problem Based Learning. Jurnal Kependidikan: Jurnal Hasil Penelitian Dan Kajian Kepustakaan Di Bidang Pendidikan, Pengajaran Dan Pembelajaran, 6(3), 578-587. https://doi.org/10.33394/jk.v6i3.2916

Febriana, R., Yusri, R., \& Delyana, H. (2020). Modul Geometri Ruang Berbasis Problem Based Learning Terhadap Kreativitas Pemecahan Masalah. Aksioma: Jurnal Program Studi Pendidikan Matematika, 9(1), 93. https://doi.org/10.24127/ajpm.v9i1.2591

Febriyanti, C., \& Seruni, S. (2015). Peran Minat dan Interaksi Siswa dengan Guru Dalam Meningkatkan Hasil Belajar Matematika. Formatif: Jurnal Ilmiah Pendidikan MIPA, 4(3), 245-254. https://doi.org/10.30998/formatif.v4i3.161

Firdaus, H., Sugiyono, \& Purnama, S. K. (2018). The Development Model of Badminton Base Technique Training Based of Audio Visual Media for The Beginner Athlete. Jurnal Pendidikan: Teori, Penelitian, Dan Pengembangan, 3(2), 210-214. https://doi.org/10.17977/jptpp.v3i2.10734

Gunantara, G., Suarjana, M., \& Riastini, P. N. (2014). Penerapan Model Pembelajaran Problem Based Learning Untuk Meningkatkan Kemampuan Pemecahahan Masalah Matematika Siswa Kelas IV. Jurnal Mimbar PGSD Universitas Pendidikan Ganesha, 2(1). https://doi.org/10.15294/kreano.v10i2.19671

Istiandaru, A., Istihapsari, V., Wardono, \& Mulyono. (2015). Problem Based Learning (PBL) dengan Pendekatan Realistik-Saintifik dan Asesmen PISA untuk Meningkatkan Kemampuan Literasi Matematika. Edumatica, 5(1), 1-11. https://doi.org/10.22437/edumatica.v5i01.2670

Juliawan, G. A., Mahadewi, L. P. P., \& Rati, W. R. (2017). Pengaruh Model Problem Based Learning (PBL) Terhadap Kemampuan Pemecahan Masalah Matematika. Mimbar PGSD, 5(2), 1-10. https://doi.org/10.23887/jjpgsd.v5i2.10881

Ladimiyanto, A. (2014). Pengaruh Implementasi Pembelajaran Berbasis Masalah dengan Model TAI dan TPS terhadap Hasil Belajar Matematika. Pythagoras: Jurnal Pendidikan Matematika, 9(2), 110125. https://doi.org/10.21831/pg.v9i2.9073

Mariani. (2017). Penerapan Model Pembelajaran Make A Match Untuk Meningkatkan Hasil Belajar Matematika Tentang Pembagian Pada Siswa Kelas II SD Muhammadiyah 4 Batu. JINoP (Jurnal Inovasi Pembelajaran), 3(2), 599. https://doi.org/10.22219/jinop.v3i2.5306

Novitasari, R. A. (2018). Peningkatan Kreativitas Dan Hasil Belajar IPA Siswa Kelas 5 SD Taruna Bangsa Melalui Pendekatan Problem Based Learning Tahun Ajaran 2017/2018. Jurnal Handayani, 7(2), 82-91. https://doi.org/10.24114/jh.v7i2.7238

Nurhayati, N., \& Angraeni, L. (2017). Analisis Kemampuan Berpikir Tingkat Tinggi Mahasiswa (Higher Order Thinking) dalam Menyelesaikan Soal Konsep Optika melalui Model Problem Based Learning. Jurnal Penelitian \& Pengembangan Pendidikan Fisika, 3(2), 119-126. https://doi.org/10.21009/1.03201

Pratiwi, E. T., \& Setyaningtyas, E. W. (2020). Kemampuan Berpikir Kritis Siswa SD dengan Model Pembelajaran Problem Based Learning dan Model Pembelajaran Project Based Learning. Jurnal Basicedu, 4(2), 379-388. https://doi.org/10.31004/basicedu.v4i4.445

Purbarani, D. A., Dantes, N., \& Adnyana, P. B. (2018). Pengaruh Problem Based Learning Berbantuan Media Audio Visual Terhadap Kemampuan Berpikir Kritis Dan Hasil Belajar Ipa Di Sekolah Dasar. Pendasi: Jurnal Pendidikan Dasar Indonesia, 2(1), 24-34. https://doi.org/10.23887/jpdi.v2i1.2689

Rais, A. A., \& Suswanto, H. (2017). Perbandingan Implementasi Model Problem Based Learning Dan Direct 
Instruction Dalam Meningkatkan Motivasi Dan Hasil Belajar Siswa Pada Mata Pelajaran Jaringan Dasar Kelas X. Jurnal Pendidikan: Teori, Penelitian, Dan Pengembangan, 2(8). https://doi.org/10.17977/jptpp.v2i8.9787

Ramlawati, Yunus, S. R., \& Insani, A. (2017). Pengaruh Model PBL (Problem Based Learning) terhadap Motivasi dan Hasil Belajar IPA Peserta Didik. Jurnal Sainsmat, 6(1), 1-14. https://ojs.unm.ac.id/sainsmat/article/view/6451

Rustinah. (2016). Meningkatkan Hasil Belajar Matematika Melalui Penerapan Metode Team Game Turnament Pada Siswa Kelas VII.1 SMP Negeri 3 Batanghari Tahun Pelajaran 2012/2013. Aksioma: Jurnal Pendidikan Matematika FKIP Universitas Muhammadiyah Metro, 5(1), 40-51. https://doi.org/10.25273/pe.v9i2.4671

Saraswati, N. L., Dibia, I. K., \& Sudiana, I. W. (2013). Pengaruh Model Pembelajaran Inkuiri Terbimbing Terhadap Hasil Belajar Matematika Siswa Kelas III SD Di Gugus I Kecamatan Buleleng. Mimbar PGSD Undiksha, 1(1). https://doi.org/10.23887/jjpgsd.v1i1.713

Setianingsih, A. I. G. A. A. - (2019). Pengaruh Model Pembelajaran Children'S Learning in Science Berbantuan Media Audio Visual Terhadap Kompetensi Pengetahuan IPA. Mimbar Ilmu, 24(1), 203-209. https://doi.org/10.23887/mi.v24i1.17452

Sucipto, S. (2017). Pengembangan Ketrampilan Berpikir Tingkat Tinggi Dengan Using Pengembangan Strategi Model Metakognitif Pembelajaran Problem Based Learning. Jurnal Pendidikan (Teori Dan Praktik), 2(1), 63-71. https://doi.org/10.26740/jp.v2n1.p77.

Sulfemi, W. B., \& Mayasari, N. (2019). Peranan Model Pembelajaran Value Clarification Technique Berbantuan Media Audio Visual Untuk Meningkatkan Hasil Belajar IPS. Jurnal Pendidikan, 20(1), 53-68. https://doi.org/10.33830/jp.v20i1.235.2019

Suwarni, N. W. (2019). Model Pembelajaran Problem Based Learning ( PBL) Dengan Media Audio Visual Untuk Meningkatkan Prestasi Belajar PKN. Mimbar Ilmu, 24(3), 330-337.

Tarigan, D. (2014). Meningkatkan Aktivitas Belajar Siswa dengan Mneggunakan Model Make A Match Pada Mata Pelajaran Matematika di Kelas V SDN 050687 Sawit Seberang. Jurnal Pendidikan Matematika, 5(1), 56-62. http://download.portalgaruda.org/article.php?article=272684\&val=5678

Wicaksana, N. (2017). Pengaruh Model Pembelajaran Open Ended Berbantuan Media Audio Visual Dan Motivasi Terhadap Kompetensi Pengetahuan Matematika. MIMBAR PGSD Undiksha, 5(2). https://doi.org/10.23887/jjpgsd.v5i2.11074

Wintari, N. L. M. D., Wiyasa, I. K. N., \& Putra, M. (2014). Implementasi Model Pembelajaran Kooperatif Tipe Team-Assisted Individualization (TAI) Dalam Upaya Meningkatkan Interaksi Dan Hasil Belajar Matematika Siswa Kelas IV SD Negeri 6 Dauh Puri Tahun Pelajaran 2013/2014. Mimbar PGSD Undiksha, 2(1). https://doi.org/10.23887/jjpgsd.v2i1.3093

Yuwono, M. R., \& Syaifuddin, M. W. (2017). Pengembangan problem based learning dengan assessment for learning berbantuan smartphone dalam pembelajaran matematika. Beta: Jurnal Tadris Matematika, 10(2), 184-202. https://doi.org/10.20414/betajtm.v10i2.116 